\title{
INDUCED-GROWTH AND YIELD RESPONSES TO THREE VARIETIES OF TOMATO (Lycopersicon esculentum Mill.) BY SODIUM AZIDE (NaN3) and GRAFTING IN WET SEASON
}

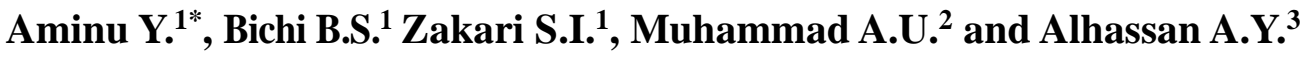 \\ ${ }^{1}$ Biology Department, College of Education and Preliminary studies, Kano State \\ ${ }^{2}$ Chemistry Department, College of Education and Preliminary studies, Kano State \\ ${ }^{3}$ Computer Science Department, College of Education and Preliminary studies, Kano State \\ *Corresponding Author Email: aminuyahayafagge @ gmail.com GSM: +2347035347997
}

\author{
Cite this article: \\ Aminu Y., Bichi B.S., Zakari \\ S.I., Muhammad A.U., \\ Alhassan A.Y. (2021), \\ Induced-Growth and Yield \\ Responses to Three Varieties \\ of Tomato (Lycopersicon \\ esculentum Mill.) by Sodium \\ Azide (NaN3) and Grafting in \\ Wet Season. African Journal \\ of Biology and Medical \\ Research 4(2), 84-91. DOI: \\ 10.52589/AJBMR- \\ JUVCHKW5.
}

\section{Manuscript History \\ Received: 9 Feb 2021 \\ Accepted: 5 March 2021 \\ Published: 25 May 2021}

Copyright $(\odot) 2020$ The Author(s). This is an Open Access article distributed under the terms of Creative Commons AttributionNonCommercial-NoDerivatives 4.0 International (CC BY-NC-ND 4.0 ), which permits anyone to share, use, reproduce and redistribute in any medium, provided the original author and source are credited.
ABSTRACT: The Effect of Sodium Azize and Grafting on Vegetative Growth PreliminaYield Parameters on Tomato in Wet Season, was investigated with the aim of inducing variability that could be exploited in the improvement of some quality traits in Tomato. The seeds of three varieties of tomato: (Roma, UC-82B and Local varieties) were treated with three different concentrations of sodium azide $(0.2 \mathrm{mM}, 0.4 \mathrm{mM}, 0.6$ $\mathrm{mM}$ and $0.0 \mathrm{mM}$ as control). The result showed highly significant difference $(\mathrm{P} \leq 0.01)$ in the effects of different concentrations of sodium azide on almost all the selected traits except on the fruit diameter where no significant difference was found. More so, the result also indicated highly significant difference $(\mathrm{P} \leq 0.01)$ among the varieties on the selected traits except in germination percent ( 1 WAP); where significant difference $(\mathrm{P} \leq 0.05)$ was found, and in number of leaves, and fruits diameters, no significant difference exists among the varieties. Furthermore, highly significant difference $(\mathrm{P} \leq 0.01)$ was found on the effects of grafting and sodium azide singly and in combine dosage as treatments on germination percent $(1$ and 2 WAP), and on number of leaves/plant. Significant difference $(\mathrm{P} \leq 0.05)$ was found on the effects of these treatments on the survival rate, while, no significant difference was found on the effects of the treatments on the number of fruits, fruit diameter, and $\mathrm{pH}$. More so, no significant differences was found in the interactions except in the interaction in the interactions of variety and treatments on the number of leaves where highly significant difference $(\mathrm{P} \leq 0.01)$ was found.

KEYWORDS: Sodium Azide Grafting, Roma, UC82, Local Rainy, Season, Mutation. 


\section{INTRODUCTION}

The cultivated tomato (Lycopersicon esculentum Mill.) belongs to the family Solanaceae (Mann A.; Gbate M.; \& Umar, A.N. 2003) and is considered as the second most important vegetable crop in the world apart from potato (Adamu, A.K., \& Aliyu, H.2007). Tomato had a nutritional and medicinal values for its content of vitamin A and C. (Hang, S.D.; Y.P. Zhao; G.Y. Wang \& Song, G.Y 2005) beside Carotenoids pigments with antioxidant properties that protect human body from free radicals damages and reduce the risk of cancer and cholesterol. Tomato is sometime being referred to as poor man's orange (Dhanavel; D., Gnanamurthy, S; \& Girija, M. 2012). It is grown in a wide range of environments comprising natural and protected conditions (Dhaliwal, M.S., Kaur, A., \& Singh, S. 2002) of both the tropical, sub-tropical and temperate parts of the world. Mutation induction offers the possibility of inducing desired attributes that either cannot be found in nature or have been lost during evaluation. Treatment with mutagens alters genes or breaks chromosomes. Gene mutations occur naturally as errors in DNA replication.

Grafting (an asexual method of propagating plants) is a method whereby tissues of one plant are encouraged to fuse with those of another plant (Anonymous, 2011). Grafting is frequently used to combine advantageous characteristics of scion and stock. For instance, branches or buds of trees known to produce good fruit are grafted to stronger trees that produce fruit of indifferent quality. Colchicine induced mutagenesis was reported to be beneficial in increasing the size of fruits and other plant parts. (Foolad, 2007).

However, one of chemical mutagens is sodium azide (NaN3) which is known to be highly mutagenic in several organisms, including plants and cause genetic diversity that affect plant growth and productivity (Addai, I. K. \& O. S. Kantanka, 2006). A chemical mutagen generally produces an induced mutations leading to the substitution, for sodium azide substitutions occurs especially on amino acid changes that alter protein function. This chemo mutagen induces a wide variation in morphology and agronomic characters when compared to normal plants (Ahloowalia, B.S. \% Maluszynski, M. 2001). The main objective of this research is to discover the mutagenic effect of Sodium azide and Grafting in some selected Traits on Three varieties in Tomato Solanum lycopersicum mill in Wet season.

\section{MATERIALS AND METHOD}

\section{Study Site}

The research was conducted in the Green House of the Botanical Garden of the Department of Biological Sciences, Ahmadu Bello University Zaria (2014). (Lat $11^{0} 12^{1} \mathrm{~N}$, Long $7^{0}, 37^{1} \mathrm{E}$, Alt 550-700 $\mathrm{m}$ above sea level).

\section{Sources of the Seeds}

Seeds of three varieties of cultivated tomato (Roma, UC82B and a local variety) were collected from the Institute for Agricultural Research (I.A.R), Ahmadu Bello University Zaria, Nigeria. 


\section{Treatment and Experimental Design}

The treatments used in the research are mutation using various concentrations of sodium azide, grafting and combination of grafting and sodium azide. Some seeds of the three tomato varieties were treated with four different concentrations of Sodium Azide $(0.2 \mathrm{mM}, 4.0 \mathrm{mM}$, $6.0 \mathrm{mM}$ and $0.0 \mathrm{mM}$ as control) respectively. The three varieties used were Roma, UC-82B and one local variety. Roma was said to flourish successfully during the rainy season while UC-82B flourishes and grows successfully during the dry season. Three different treatments were formed: Chemically treated with sodium azide, grafted and combination of grafting and sodium azide treated plants were grown during the rainy season and dry season. The treated plants were grown in 45 polythene bags arranged in a Completely Randomized Design (CRD) with three repetitions in each season.

The seeds used for rootstocks were planted 2 days prior to that of the shoots. Tongue grafting approach was used. This is due to the relative advantage of the method over others such as its being used on larger plants, three times faster than other techniques, high success rate and is easy to handle. After two weeks of planting, and a day prior to grafting, the plants used for grafting were watered fully to make them turgid. One-fourth of the plants used for rootstock were cut at slant early in the morning. The shoot was also cut in the same way. The two cut ends were placed in direct contact and use a small clip to hold the cut surfaces together. This was repeated in the $3^{\text {rd }}$ and $4^{\text {th }}$ week of planting, while the remainder was left as control as described in McVoy (2005) protocol.

After two weeks of planting, the plants treated with the mutagen that germinated were grafted by transferring the scions of one variety to the stock of another variety. Similarly, the plants that are not treated with the mutagen were grafted. More so, the plants that are treated with the mutagen only were allowed to grow without grafting. The untreated plants were allowed to grow as control.

Mean Squares for the Effects of Grafting and Sodium Azide on Some Varieties of Tomato in Wet Season

\begin{tabular}{|c|c|c|c|c|c|c|c|c|}
\hline $\begin{array}{c}\text { Sources of } \\
\text { Variation }\end{array}$ & DF & $\begin{array}{c}\text { Germination } \\
\% \\
(1 \text { WAP })\end{array}$ & $\begin{array}{c}\text { Germination } \\
\% \\
\text { (2 WAP })\end{array}$ & $\begin{array}{l}\text { Survival } \\
\text { Rate (\%) }\end{array}$ & $\begin{array}{c}\begin{array}{c}\text { Number } \\
\text { of }\end{array} \\
\text { Leaves }\end{array}$ & $\begin{array}{c}\text { Number } \\
\text { of } \\
\text { Fruits/plant }\end{array}$ & $\begin{array}{c}\text { Fruit } \\
\text { Diameter } \\
(\mathbf{c m})\end{array}$ & pH \\
\hline Replication & 2 & $442.51^{\mathrm{ns}}$ & $219.42^{\mathrm{ns}}$ & $881.07 *$ & $53.86^{* *}$ & $4.39^{\mathrm{ns}}$ & $0.36^{*}$ & $0.03 *$ \\
\hline Concentration & 3 & $12191.08 * *$ & $6386.37 * *$ & $7181.49 * *$ & $171.27 * *$ & $99.38 * *$ & $0.19^{\text {ns }}$ & $0.40 * *$ \\
\hline Variety & 2 & $2248.15^{*}$ & $4525.46^{* *}$ & $2823.29 * *$ & $6.69^{\mathrm{ns}}$ & $33.12 * *$ & $0.08^{\mathrm{ns}}$ & $0.21 * *$ \\
\hline Treatments & 2 & $12824.68 * *$ & $7275.75 * *$ & $790.88^{*}$ & $45.44 * *$ & $7.70^{\mathrm{ns}}$ & $0.22^{\mathrm{ns}}$ & $0.02^{\mathrm{ns}}$ \\
\hline $\begin{array}{l}\text { Conc } x \\
\text { Variety }\end{array}$ & 6 & $206.41^{\mathrm{ns}}$ & $122.25^{\mathrm{ns}}$ & $34.16^{\text {ns }}$ & $1.71^{\mathrm{ns}}$ & $6.06^{\mathrm{ns}}$ & $0.04^{\mathrm{ns}}$ & $0.009^{\mathrm{ns}}$ \\
\hline $\begin{array}{l}\text { Conc } x \\
\text { Treatment }\end{array}$ & 6 & $668.55^{\mathrm{ns}}$ & $185.93^{\text {ns }}$ & $88.22^{\text {ns }}$ & $4.53^{\mathrm{ns}}$ & $3.83^{\mathrm{ns}}$ & $0.06^{\mathrm{ns}}$ & $0.004^{\mathrm{ns}}$ \\
\hline $\begin{array}{l}\text { Variety } x \\
\text { Treatment }\end{array}$ & 4 & $1917.81^{\mathrm{ns}}$ & $632.57^{\mathrm{ns}}$ & $287.79^{\mathrm{ns}}$ & $33.72 * *$ & $11.45^{\mathrm{ns}}$ & $0.03^{\mathrm{ns}}$ & $0.01^{\mathrm{ns}}$ \\
\hline
\end{tabular}


African Journal of Biology and Medical Research

ISSN: 2689-534X

Volume 4, Issue 2, 2021 (pp. 84-91)

www.abjournals.org

\begin{tabular}{|c|c|c|c|c|c|c|c|}
\hline $\begin{array}{l}\text { Conc } x \\
\text { Variety } x \\
\text { Treatment }\end{array}$ & $12169.41^{\mathrm{ns}}$ & $131.94^{\mathrm{ns}}$ & $123.29^{\text {ns }}$ & $2.05^{\mathrm{ns}}$ & $3.89^{\mathrm{ns}}$ & $0.04^{\text {ns }}$ & $0.002^{\mathrm{ns}}$ \\
\hline Error & 142395.64 & 196.89 & 143.01 & 3.58 & 3.05 & 0.07 & 0.008 \\
\hline
\end{tabular}

Keys: $n s=$ No significant difference $*=$ Significant difference $(P \leq 0.05) * *=$ Highly significant difference $(P \leq 0.01)$

The result for the analysis of variance of the Effects of Sodium Azide and Grafting on Three Varieties of Tomato during the wet season was presented in the table above. The result showed highly significant difference $(\mathrm{P} \leq 0.01)$ in the effects of different concentrations of sodium azide on almost all the selected traits except on the fruit diameter where no significant difference was found. More so, the result indicated highly significant difference $(\mathrm{P} \leq 0.01)$ among the varieties on the selected traits except in germination percent (1 WAP); where significant difference $(\mathrm{P} \leq 0.05)$ was found, and in number of leaves and fruits diameters where no significant difference exists among the varieties. Furthermore, highly significant difference $(\mathrm{P} \leq 0.01)$ was found on the effects of grafting and sodium azide singly and in combine dosage as treatments on germination percentages ( 1 and 2 WAP) and number of leaves. Significant difference $(\mathrm{P} \leq 0.05)$ was found on the effects of these treatments on the survival rate, while, no significant difference was found on the effects of the treatments on the number of fruits, fruit diameter and $\mathrm{pH}$. More so, no significant differences was found in the interactions except in the interaction in the interactions of variety and treatments on the number of leaves where highly significant difference $(\mathrm{P} \leq 0.01)$ was found.

\section{DISCUSSION}

The distinct differences observed in most of the quantitative and qualitative traits among the sodium azide induced mutants of tomato evaluated showed significant improvements in the selected traits. Although there were few traits with no significant differences in responses to the applied treatments; the ability of the mutants to germinate faster after one and two weeks of planting in respect to the controls showed that the mutagenic treatments induced increase enzymatic activities, which could be responsible for the early germination. This finding is in agreement with the findings of (Mensah, J.K., Akomeah, P.A., \& Ekpekurede, E.O. 2005) who reported decreased in germination with increase in the dose of chemical mutagens. In the present investigation, germination, survival percentage, and leaf number decreased with increasing concentration of sodium azide. This finding conformed to the earlier report by (Ahloowalia \& Maluszynski 2001) that, the viable mutants observed are mainly dependable measure of genetic effect in mutagen. The increased in the number of leaves, and number of fruits per plant due to sodium azide treatments is also in conformity with the work of (Adamu \& Aliyu 2007) who reported increased in growth and yield parameters of tomato due to sodium azide treatments. There were reductions in the germination and survival percentages with increasing concentrations for both chemicals in the generation. Reductions in germination and survival percentages due to the effects of mutagens on various crop plants have earlier been documented by (Mensah et al. 2005). 
The increased in the number of leaves and leaf area among the mutants signifies the ability of the mutagen (sodium azide) to initiate more foliar buds. This finding agrees with the work of (Maluszynski, M., Szarejko, I., Barriga, P., \& Balcerzyk, A. 2001) who independently reported an increase in leaf number and leaf area among Zeamays mutants. More so, the improvement in the growth and yield components of tomato due to sodium azide treatments stressed the effect of mutation on the growth and yield of plants. This is in conformity to the work of (Adamu et al. 2002) when groundnut was treated with gamma rays (Sheeba, A., Abumalarmalhi, J., Babu, S., and Ibrahim, S. N.M. 2005). Mutagenic effects of gamma rays and EMS in M1 generation in sesame. Resources on Crops 6(2): 300-306. When gamma rays and EMS were used to treat Sesanum indicum L. where seed germination, seedling survival, and pollen fertility were reduced significantly with an increase in dosage levels of both mutagens.

However, in contrast, (Sasi, A., Dhanavel, D., \& Paradai, P. 2005). Effect of chemical Mutagensis on bhendi (Abelmoschusesculentus (L.) moench var. MDU-1). ResourcesonCrops 6(2) 253-256showed that all plant mutant types registered lower yields compared to their parents in the study of the effects of diethylsulphate and EMS on Okra (Abelmoschus esculentum (L.) var. MDU-1). The increased in fruit quality such as $\mathrm{pH}$ and fruit number due to induced mutagenesis by sodium azide signifies the vital role played by the mutagen in improving the quality traits of tomato. The increased in dry weights of the tomato varieties due to sodium azide treatments is in contrast to the findings of (Ikhajiagbe, B., Mshembula, B.P., and Mensah, J.K. 2012).

The increased survival rates of the grafted tomato recorded showed excellent percentage of grafting success after 12 days in the incubation. This is similar to the earlier report by (Anonymous, 2011) that the percentage of survival ratios of all types of grafting was 97, 98 and $99 \%$ for splicing, top and tongue respectively. The survival rate of grafted plants depends on compatibility between scion and rootstock, quality and age of seedlings, quality of the joined section, and post-grafting management. Different grafting techniques are adapted for different scions and rootstocks depending on grafting objectives, farmer's experience, and post-grafting management conditions as described by (Hang, S.D., Y.P. Zhao, G.Y., Wang \& Song, G.Y. 2005).

Higher fruit yield parameters found in this study could be due to the fact that grafting combines novel traits of the two grafted plants after grafting operation. This has also been reported by (Tsouvaltzis, P.I., Siomos, A.S., and Dogras, K.C. 2004). The increased pH of the juice in grafted plants is in contrast to the findings of (Leoni, S., R. Grudina, M. Cadinu, B. Madeddu \& M.G. Carletti, 1990): The influence of four Root-stocks on some melon hybrids and a cultivar in greenhouse. ActaHorticulturae 287: 127-134. (Romano \& Paratore 2001) who found that fruit descriptive and qualitative characteristics were not affected by grafting. But (Lee, 1994) found an increase in yield which was attributed to the vigour of the rootstock and the higher uptake of water and nutrients. (Passam, H.C., Stylianoy, M., and Kotsiras, A.,2005) found that eggplants grafted on to two tomato rootstocks gave a higher yield and bigger fruit size than those grafted on to two eggplant rootstocks, but the mineral composition of fruits from grafted plants did not differ from that of non-grafted plants.

The fruit characteristics of grafted plants were compared with those of non-grafted plants. The results showed that the fruit index (diameter and number of fruits) were significantly influenced by grafting. The results agree with those reported by (Lee, 1994) who concluded that fruit shapes are influenced by rootstocks. (Pogonyi, A., Pek, Z., Helyes, L., and Lugasi, 
A., 2005) reported that when Lemance $F_{1}$ was grafted onto Beaufort rootstock, increased yield was caused mainly by higher average fruit weight. (Ibrahim, A., Wahb-Allah, M., Abdel-Razzak, H., \& Alsadon, A. 2014) also found that the total number of fruits per truss in non-grafted plants was statistically different from the total for grafted plants.

The results of the study showed that tomato grafting on suitable rootstocks had positive effects on the yield. In grafted combinations, the total fruit yield per plant increased significantly in comparison with that of the control plants. (Ibrahim M., Munira, M.K., Kabir, M.S., Islam, A.K.M.S., and Miah, M.M.U. 2001) observed similar results in grafted and nongrafted tomato plants. These investigators suggested that the higher yield of fruit from grafted tomato plants was most likely an effect of the vigorous root system of the rootstock. According to (Lee, 1994), the increased yield of grafted plants is also believed to be due to enhanced water and mineral uptake. The $\mathrm{pH}$ value also plays an important role in determining fruit quality characteristics. Many studies focused on $\mathrm{pH}$ as a key element in tomato selection as stressed by Hong (Tsou, 1998). The analyzed results showed that the $\mathrm{pH}$ values of tomato fruit increased among the grafted plants. This is in conformity to the findings of (Kuzucu C., Kaynas K., Kuzucu F.C., Erken N.T., Kaya S., Daydır H.U., 2004) who also reported that Koral, Mobil and H-2274 (fresh tomato) have a $\mathrm{pH}$ value of 4.31, 4.33 and 4.33, respectively; but is contrary to the work of (Khah, E.M., Kakava, E., Mavromatis, A., Chachalis, D., and Goulas, C. 2006) who found that fruit $\mathrm{pH}$ values were not affected by grafting.

\section{CONCLUSION}

It was generally concluded that, $0.2 \mathrm{mM}$ concentration of sodium azide $\left(\mathrm{NaN}_{3}\right)$ and grafting are significant in inducing variability that could be exploited in the improvement of highly economic crops like tomato. It was also concluded that, the mutants and grafted tomato can be grown all the year round (both during the rainy and dry seasons).

\section{REFERENCES}

Adamu, A. K., Oluranju, P. E., Bate, J. A.,and Ogunlade, O. T. (2002): Radio-sensitivity and effective dose determination in groundnut (Arachishypogaea L.) irradiated with gamma-rays. JournalAgricultureandEnvironment3(1): 17-84.

Adamu, A. K.,and Aliyu, H.(2007): Morphological effects of sodium azide on tomato (LycopersiconesculentumMill). ScienceWorldJournal 2(4): 9-12

Addai, I.K. and O. S. Kantanka, (2006). Effect of $6^{6} \mathrm{Co}$ gamma irradiation on storability of soybean seed. Asian J. Plant Sci., 5: 221-225.

Ahloowalia, B.S. and Maluszynski, M. (2001): Induced Mutation: A new paradigm in plant Breeding.Euphytica, 118:167-173.

Anonymous (2011): Grafting. http://www.wikipedia.org. Retrieved $23^{\text {rd }}$ April, 2014. 1-7pp.

Deepalakshmi, A.J. (2000): Creation of variability in black gram (Vignamungo L. Hepper) through induced mutagenesis. MSc.(Ag.) Thesis (Unpublished), Tamil Nadu Agricultural. University, Coimbatore. 1-50pp.

Dhaliwal, M.S., Kaur, A., and Singh, S. (2002): Genetic analysis and correlations involving populations derived from L. esculentum x L. pimpinellifolium crossesof tomato. Journal of 
Genetics and Breeding 56:345-352.

Dhanavel, D., Gnanamurthy, S., and Girija, M. (2012): Effect of gamma rays on induced chromosomal variation in cowpea (Vignaunguiculata L. Walp.). International Journal of Current Science 245 - 250.

Foolad, M.R. (2007): Genome mapping and molecular breeding of tomato. International Journal of Plant Genomics 643-58.

Hang, S.D., Y.P. Zhao, G.Y. Wang and Song,G.Y. (2005): Vegetable Grafting, China Agriculture Press, Beijng, China. 1-6pp.

Hong, T.L., and Tsou, S.C.S. (1998): Determination of tomato quality by near infrared spectroscopy. Journal of Near Infrared Spectroscopy 6: 321-324.

Ibrahim M., Munira, M.K., Kabir, M.S., Islam, A.K.M.S., and Miah, M.M.U. (2001): Seed germination and graft compatibility of wild Solanum as rootstock of tomato. Asian Journal of Biological Sciences, 1: 701-703.

Ibrahim, A., Wahb-Allah, M., Abdel-Razzak, H., and Alsadon, A. (2014): Growth, Yield, Quality and Water Use Efficiency of Grafted Tomato Plants Grown in Greenhouse under Different Irrigation Levels. Life Science Journal 11(2):118-126=

Ikhajiagbe, B., Mshembula, B.P.,and Mensah, J.K. (2012): Comparative assessment of the mutagenic effects of sodium azide on some selected growth and yield parameters of five accessions of cowpea - Tvu-3615, Tvu-2521, Tvu-3541, Tvu-3485 and Tvu-3574.Arch. Appl. Sci. Res.4 (4):1682-1691

Khah, E.M., Kakava, E., Mavromatis, A., Chachalis, D., and Goulas, C. (2006): Effect of grafting on growth and yield of tomato (Lycopersiconesculentum Mill.)in greenhouse and open-field. Journal of AppliedHorticulture 8:3-7.

Kharkwal, M.C and Q.Y. Shu, (2009). The Role of induced Mutations in World Food Security. In: Induced Plant Mutations in the Genomics Era, Shu, Q.Y. (Ed.)., Food and Agriculture Organization of the United Nations, Rome, Italy, pp: 33-38.

Kumar, V.A., Kumari, R.U., Amutha, R.,Kumar, T.S., Hepziba, S.J., and Kumar, C.R.A.(2009):Effect of chemical mutagen on expression of characters in arid legume pulsecowpea(VignaunguiculataL.Walp.).ResearchJournalofAgricultureandBiologicalSc iences 5 (6): 1115 - 1120.

Kuzucu C., Kaynas K., Kuzucu F.C., Erken N.T., Kaya S., Daydır H.U.,(2004): Bazı domatesçeşitlerinin verim ve kalite özelliklerinin belirlenmesi (Determination of yield and quality characteristics of some tomato varieties). In: VSebze tarımı sempozyumu bildiri kitab1, 21-24 September,2004. Çanakkale, Turkey: 288-294..

Lee, J. M. (1994): Cultivation of Grafted Vegetables I. Current Status, Grafting Methods, and Benefits.Horticultural Science. 29(4):235-239.

Leoni, S., R. Grudina, M. Cadinu, B. Madeddu and M.G. Carletti, (1990): The influence of four Root-stocks on some melon hybrids and a cultivar in greenhouse. ActaHorticulturae 287: 127-134.

Maluszynski, M., Szarejko, I., Barriga, P., and Balcerzyk, A. (2001): Heterosis in crop mutant crosses and production of high yielding lines, using doubled haploid systems. Euphytica. 120:387-398.

Mann A., Gbate M., and Umar, A.N. (2003): MedicinalandeconomicPlantsofNupeland. Jube-evans books and publications, Bida, Niger state. 1-135pp.

Mensah, J.K., Akomeah, P.A.,and Ekpekurede, E.O.(2005): Gamma irradiation induced variation of yieldparameters in cowpea (Vignaunguiculata (L.) Walp.) GlobalJournalofPure and AppliedSciences 11(3): 327-330. 
Mensah, J.K., and Akomeah, P.A.(1997): Mutagenic effects of hydroxylamineand streptomycin on the growth and seed yield of the cowpea,Vignaunguiculata L. Walp. LegumeResearch 15:3944.

Mensah, J.K., Obadoni, B.O., Akomeah, P.A., Ikhajiagbe, B., and Ajibulu, J.(2007): The effects of Sodium azide and Colchicine treatments on morphological and yield traits of sesame seed (SesamumindicumL.). AfricanJournalofBiotechnology6(5):534-538.

Novak, F. J. and H. Brunner, 1992. Plant breeding: Induced mutation technology for crop improvement. IAEA Bull., 4: 25-32.

Passam, H.C., Stylianoy, M., and Kotsiras, A.(2005): Performance of Eggplant Grafted on Tomato and Eggplant Rootstocks. European Journal of Horticultural Science, 70(30): 130-mnv134.

Pogonyi, A., Pek, Z., Helyes, L., and Lugasi, A.(2005): Grafting tomatoes for early forcing inspring has a major impact on the overall quality of main fruit components. ActaAlimentaria 34:453-462

Pulgar, G., Rivero, R.M., Moreno, D.A., Lopez-Lefebre, L.R., Villora, G.,Baghour, M., and Romero, L. (1998): Micronutrientes en hojas de sandía injertadas. In: VIISimposionacional-IIIIbéricosobreNutriciónMineraldelasPlantas. Gárate A. (Ed.). Universidad Autónoma de Madrid, Madrid. 255-260.

Sasi, A., Dhanavel, D.,and Paradai, P. (2005): Effect of chemical Mutagensis on bhendi (Abelmoschusesculentus (L.) moench var. MDU-1). ResourcesonCrops 6(2) 253-256.

Sheeba, A., Abumalarmalhi, J., Babu, S., and Ibrahim, S. N.M. (2005): Mutagenic effects of gammarays and EMS in $\mathrm{M}_{1}$ generation in sesame. ResourcesonCrops6(2): 300-306.

Thanga Hemavathy, A. (2002): Creation of variation in black gram (VignamungoL. Hepper). M.Sc. (Ag.) Thesis, Tamil Nadu Agric. Univ. Coimbatore. 1-79pp.

Tsouvaltzis, P.I., Siomos, A.S., and Dogras, K.C.(2004): The effect of the two tomatoes grafting on the performance, earliness and fruit quality. Proc. $21^{\text {st }}$ Pan-Hellenic Congress of the Greek Society for Horticultural Science. Ioannina, Greece, 8-10 October 2003. Vol. 11: 51-55. 